$1 \mathrm{P} 211$

\section{ラフト中でのアミロイド前駆体タンパク質の膜貫通部位のニ 量化にコレステロールが与える影響}

Cholesterols affect to the association of the transmembrane region of Amyloid Precursor Protein in the raft

Naoyuki Miyashita ${ }^{1,2}$, Fumiko Ogushi $^{3}$, Yuji Sugita ${ }^{1,2,4}\left({ }^{1}\right.$ RIKEN Quantitative Biology Center, ${ }^{2}$ RIKEN AICS, ${ }^{3}$ Ochanomizu University, ${ }^{4}$ RIKEN)

The bio-membrane often forms nano-domains, rafts, and provides a special environment to a membrane protein. Amyloid precursor protein (APP) produces an Amyloid beta peptide, which is the source of senile plaque in a brain. The APP forms dimer or monomer conformations in the biomembrane. Recent experiments have suggested that the cholesterols attach to the Gly-xxx-Gly motif in the raft-like environments. However, the Glyxxx-Gly motif is the important interface of the dimerization of APP too. We investigated how the cholesterols compete with the dimerization of APP, using Martini Coarse Grained (CG) model simulations. The cholesterols, of course, favored the dimer interface. Our results suggested that the cholesterols assist to the association of APP too.

\section{$1 \mathrm{P} 212$}

\section{リポソーム内膜タンパク質合成が誘起する脂質膜の形態変化}

Morphological changes of the lipid membrane induced by inliposome membrane protein synthesis

Kosuke Okamura, Hajime Watanabe, Tomoaki Matsuura (Department of biotechnology, Graduate school of engineering Osaka university)

Letm1, one of the mitochondrial inner membrane proteins, is assumed to be involved in the morphological changes of mitochondria. In vivo, it has been found that Letm1 dysfunction induced by knockdown or knockout experiments resulting morphological abnormalities of mitochondria However, the exact role of Letm1 on the membrane morphology remains unclear. We, thus, aimed to elucidate it by the bottom-up approach. We synthesized Letm1 using a reconstituted in vitro transcription-translation system (the PURE system) inside a cell-size liposome, thereby investigating the role of the membrane protein on the dynamics of the cellular membrane. We observed clear morphological changes of the lipid membrane by synthesizing Letm1 inside the liposome.

$1 \mathrm{P} 213$

\section{光応答 DNA と細胞サイズリポソームの融合による人工細胞 型分子ロボット}

Artificial cell-based molecular robots by fusion of light responsive DNA and cell-sized liposomes

Masamune Morita ${ }^{1}$, Hao Li ${ }^{1}$, Tomonori Shibata ${ }^{2}$, Hirohide Saito ${ }^{2,3}$, Masahiro Takinoue $^{1,4}$ ('Interdisciplinary Grad. Sch. Sci. and Eng., Tokyo Institute of Technology, ${ }^{2}$ Center for iPS Cell Res. and App. (CiRA), Kyoto University, ${ }^{3}$ The Hakubi Center for Adv. Res., Kyoto University, ${ }^{4}$ PRESTO, JST)

Molecular robotics has attracted much attention as a novel engineering concept of self-assembled biological systems. Although nano-sized molecular robots based on the DNA/RNA molecules have been reported, micro-sized molecular robots have never been developed yet. Here, we proposed an artificial cell-based molecular robots as an integrated system of designed DNA/RNA molecules and cell-sized liposomes. In this system, we designed that RNA transcription starts by light stimulation, and the RNA and proteins autonomously self-assembles into a RNA-protein complex. We will report the more complex functions within interaction between RNA-protein complex and liposome.

\title{
チューブリン封入ジャイアントリポソームの温度・静水圧変
} 化による可逆的形態制御

Reversible morphological control of tubulin-encapsulated giant-liposomes induced by change of hydrostatic pressure and temperature

Masahito Hayashi ${ }^{1}$, Masayoshi Nishiyama ${ }^{2}$, Yuki Kazayama ${ }^{3}$, Taro Toyota ${ }^{3,4}$, Kingo Takiguchi ${ }^{1}$ ( ${ }^{1}$ Grad. Sch. Sci. Nagoya Univ., ${ }^{2}$ Kyoto Univ., iCeMS, ${ }^{3}$ Grad. Sch. Arts Sci., Univ. of Tokyo, ${ }^{4}$ Res. Center Complex Sys. Biol., Univ. of Tokyo)

We examined the effect of hydrostatic pressure and temperature on the tubulin-encapsulated giant-liposomes. Many of the liposomes kept a bipolar shape with a central sphere and two tubular protrusions that aligned in a straight line at room temperature and ambient pressure as reported previously (Kaneko et.al., 1998). Immediately after the application of high pressure $(80 \mathrm{MPa})$ or low temperature $\left(4^{\circ} \mathrm{C}\right)$, the protrusions shrunk within several tens of seconds. This process was reversible; after the pressure was released or the temperature increased to $25^{\circ} \mathrm{C}$, the protrusions regenerated within several minutes. Our results demonstrate that the shape of giant liposomes is controllable using the polymerization and depolymerization process of microtubules.

\section{$1 \mathrm{P} 215$ 粘弾性流体を内包したリポソームの膜変形}

Effects of viscoelastic cytoplasm in liposome on the shape deformation

Miho Yanagisawa ${ }^{1}$, Kei Fujiwara ${ }^{2}\left({ }^{1}\right.$ Dept. Appl. Phys., Tokyo Univ. Agric. Technol., ${ }^{2}$ Dept. Biosci. Info., Keio Univ.)

Liposomes have been used as a model of living cells. Under a hypotonic condition, the liposomes deform their shapes to minimize the bending energy. We investigated how the existence of macromolecules inside affects the liposomal deformation. We prepared liposomes containing 80 $\mathrm{mg} / \mathrm{ml}$ macromolecules of BSA or a protein mixture extracted from Escherichia coli. The macromolecules were concentrated up to the physiological concentration, i.e. $300 \mathrm{mg} / \mathrm{ml}$. Consequently, the condensation process and the shape deformation differed between BSAand Cell Eextract-containing liposomes. These results strongly suggested that the crowded environment in cells is different from that found in typical single-component systems

[1] K. Fujiwara and M. Yanagisawa, ACS Synth. Biol., in press.

\section{表面張カレプリカ交換分子動カ学法の開発と生体膜系への 応用}

Surface-tension replica-exchange molecular dynamics simulations of biological membrane systems

Takaharu Mori, Yuji Sugita (RIKEN)

Conformational sampling is fundamentally important for simulating complex bio-molecular systems. Here, we propose a new enhanced simulation method for membrane systems, which we call the surfacetension replica-exchange molecular dynamics method. We tested the method on two biological membrane systems: DPPC lipid bilayers and WALP23-POPC membranes. During these simulations, large-scale lateral deformation of the membranes took place, and there was accelerated lateral diffusion of DPPC lipid molecules compared with conventional MD simulation. We succeeded to predict the optimal orientation of WALP23 based on the free-energy calculation. Our method could be applicable to a wide variety of biological membrane systems. 